\title{
LIGHT AND ELECTRON MICROSCOPIC STUDIES OF THE HARDERIAN GLAND IN BILGORAJSKA GOOSE (ANSER ANSER)
}

\author{
JoAnna KlećKowsKa-Nawrot, ${ }^{*}$ * AleKsandra Chęć, ${ }^{2}$ \\ Karolina GoŹDZIEWSKA-HARŁAJCZUK, ${ }^{1}$ \\ RENATA NOWACZYK ${ }^{1}$ and KAROLINA BARSZCZ ${ }^{3}$
}

\author{
${ }^{1}$ Department of Animal Physiology and Biostructure, Faculty of Veterinary Medicine, \\ University of Environmental and Life Sciences, Kozuchowska 1/3, 51-631 Wroclaw, Poland \\ ${ }^{2}$ First year student of the Faculty of Veterinary Medicine, \\ Wroclaw University of Environmental and Life Sciences, Wroclaw, Poland \\ ${ }^{3}$ Department of Morphological Sciences, Faculty of Veterinary Medicine, \\ Warsaw University of Life Sciences, 159 Nowoursynowska, 02-776 Warsaw, Poland
}

(Received: May 19, 2014; accepted: February 16, 2015)

\begin{abstract}
The Harderian gland (HG) in birds is the dominant orbital gland, which plays an important role in immunological response. Tissue sections taken from adult females of Bilgorajska goose were stained with hematoxylin-eosin, Azan, PAS, AB pH 2.5, AF and HDI. Based on the histological structure the HG in Bilgorajska geese had compound tubular structure with multiple lobules and two types of epithelial cells lining the tubules. Epithelial cells in the central part of the lobes were dark in color and contained serous fluid, while in the deeper layers, epithelial cells were lightly coloured and contained mucous fluid. Histochemical studies showed the presence of neutral mucopolysaccharides and carboxylated acid mucopolysaccharides in the secretory cells. The small number of single plasma cells were present in HDI staining below the basement membrane of the secondary and primary ducts, near the crypts of the main duct. TEM study demonstrated that plasma cells had a large nucleus with condensed heterochromatin and were rich in rough endoplasmic reticulum. The knowledge of gland's structure, and above all an analysis of the immune system components may affect clinical practice and properly conducted immunization of birds.
\end{abstract}

Keywords: Harderian gland - accessory organ of the eye - Bilgorajska goose - immune cells - light microscopy - electron microscopic studies

\section{INTRODUCTION}

The Harderian gland (HG), also known as the gland of the third eyelid (glandula membrane nictitantis) [22-23], was first described in the red and fallow deer by Swiss physician Johann Jacob Harder in 1694 [15]. Brobby et al. [4] conducted the first studies on HG of birds. In 1880, MacLeod has described the anatomy and histology of ducks' HG [5]. The HG is a dominant orbital gland in birds $[4-5,12,20]$ which lies in the ventronasal quadrant of the orbit near inter-orbital septum, and secrets via its duct into the conjunctival space between the third eyelid and the cornea [22].

\footnotetext{
*Corresponding author; e-mail address: lestat_v@poczta.onet.pl
} 
The HG has also been discovered in amphibians, reptiles, birds, and mammals [29]. Avian HG can display three types of histological structure. Type I has a compound tubulo-acinar structure with a lobule composed of a single type of epithelial cells and with a large age-dependent population of plasma cells in the interstitium of the gland $[1,3,5,14,29]$. Type II has a compound tubular structure, lobule with two types of epithelial cells lining the tubule and much smaller population of plasma cells $[3,5$, 29]. Type III can be regarded as "mixed" structures [5, 29]. According to Sakai [26], cited after Shirama et al. [29], the HG produces a mucous secretion in amphibians, serous or sero-mucous in reptiles, mucous in birds, and lipid secretion in mammals.

The usual function of this gland is to lubricate the surface of the eyeball and third eyelid [20]. The gland is also a peripheral lymphoepithelial organ which, together with the spleen, the bursa of Fabricius and the caecal tonsils form a system of avian organs that determines both general and local immunity [14]. According to Dimitrov [13], the HG in birds is a lymphoepithelial organ that almost entirely ensures local immunity of the eye orbit mainly due to IgA. In marine birds and also in waterfowl, as Anatidae, the $\mathrm{HG}$ possesses salt-excreting properties [7]. The role of $\mathrm{HG}$ involves also production of pheromones, lubrication of the cornea and third eyelid, synthesis

of hormones, providing growth factors, osmoregulation in some rodents, is a site of immune response - particularly in birds (producing $\operatorname{IgA}$, IgG, $\operatorname{IgM}$ ), provides salt in mare turtles, and helps in thermoregulation in some rodents $[2-3,8,9,15-16,23$, 25-26]. The HG may also be involved in the functioning of the pineal-hypothalamichypophyseal-gonadal axis $[6,19,25,28]$.

The aim of the present study was to demonstrate the normal anatomical, histological, histochemical and ultrastructural findings in the HG of Bilgorajska goose with description of the immune cells.

\section{MATERIALS AND METHODS}

The studies were conducted on the HG of 13 adult females of Bilgorajska geese (Anser anser) (10 months old) with a body weight between 4.5 to $7.0 \mathrm{~kg}$. Material for the study derived from the flock kept by the Division of Poultry Breeding, Wroclaw University of Environmental and Life Sciences. This material was obtained following the natural death of the birds. The samples of HG were collected immediately after death. Since 2000 Bilgorajska geese have been placed on the World Watch List for Domestic Animal Diversity (FAO, UNEP) while since 2011 Bilgorajska goose is part of the preservation program of genetic resources of geese populations, the present studies were approved by the II Local Ethics Committee in Wroclaw for Experiments on Animals. Morphometric measurements (length, width, thickness) of HG were performed using an electronic slide caliper with an accuracy of $0.1 \mathrm{~mm}$. The shape of HG and its topography (holotopy and syntopy) were also examined in the study. Research material was directly fixed in $4 \%$ buffered formaldehyde, rinsed in running water for $24 \mathrm{~h}$, then the material was processed in vacuum tissue processor - ETP (RVG3, INTELSINT, Italy), embedded in paraffin and cut on a sliding microtome 
Slide 2003 (PFM Medicine AG, Köln) into 3-4 $\mu \mathrm{m}$ sections. Then sections were stained with hematoxylin-eosin, Azan, trichrome periodic acid-Schiff staining - PAS, Alcian blue - AB, $\mathrm{pH}$ 2.5, aldehyde fuchsin - AF, Hale's dialysed iron staining - HDI methods and were examined using a Zeiss Axio Scope A 1 light microscope (Carl Zeiss, Jena). PAS, AB pH 2.5, AF and HDI stainings' scoring system was based on standard protocol described previously [30]. For electron microscopy collected materials were fixed in $2.5 \%$ glutaraldehyde diluted in $0.1 \mathrm{M}$ phosphate buffer ( $\mathrm{pH} 7.4)$ for 3 weeks at $4{ }^{\circ} \mathrm{C}$, then rinsed in phosphate buffer. The materials were then postfixed in $4 \% \mathrm{OsO}_{4}$ for $2 \mathrm{~h}$ at room temperature. After rinsing in phosphate buffer, the samples were dehydrated in graded acetone series (from 30 to 100\%). Dehydrated materials were embedded in Epon 812 epoxide resin. Blocks were cut into $70 \mathrm{~nm}$ sections using an MTX ultramicrotome (Leica Microsystem, Wetzlar, Germany). Preparations were observed with a EVO LS 15 Zeiss transmission electron microscope (Carl Zeiss, Germany).

\section{RESULTS}

The HG was located in the ventronasal angle of the orbit near the inter-orbital septum, between the medial rectus muscle, pyramidal muscle of the third eyelid and ventral oblique muscle. It was oval in shape and light pink in color. The mean size (length $\times$ width $\times$ thickness with SD) of the HG was $15.3( \pm 1.0) \times 9.8( \pm 0.7) \times 4.7$ $( \pm 0.4) \mathrm{mm}$. A single secretory duct was leaving each gland, with the orifice located in the lower conjunctival sac between the third eyelid and the cornea. The average length of the main duct was $7.55( \pm 0.5) \mathrm{mm}$. The HG was covered with a thin connective tissue capsule that projected inward to the connective tissue trabeculae, dividing the stroma of the gland into lobes. In the connective tissue trabeculae the presence of adipose tissue, large number of blood vessels, collagenous and elastic fibers were found. The HG had a compound tubular structure with a single lobule type that emptied into a wide lumen (Fig. 1a). It had a small number of plasma cells and lymphocytes. The plasma cells were present as single cell and were found below the basal membrane of the secondary and primary ducts, near the crypts of the main duct (Fig. 1c). The plasma cells were of round to ovoid form with eccentrically placed round nucleus and an intensely basophilic cytoplasm. No plasma cell was observed beneath the capsule. The tested HGs had a merocrine mode of secretion. The multiple lobes had two types of epithelial cells in the lining of the tubule. Epithelial cells in the central part of the lobes were dark in color and contained serous fluid (primary ducts), while in the deeper layers, epithelial cells were lightly tinged and contained mucous fluid (secondary ducts) (Fig. 1a). The primary ducts were lined by a single layer of high columnar epithelial cells with spherical or oval nuclei concentrated near the base of the cell. The secondary ducts were lined by cuboidal cells. The main single duct was located centrally and had an irregular lumen. Epithelium of the main duct was composed of tall cylindrical cells, with the oval nuclei located in the basal part of the cell (Fig. 1b). Numerous goblet cells were observed in the epithelium of 
the main duct in the central part of corpus glandulae (Fig. 1b). The myoepithelial cells were observed at the base of the ductal epithelium. The presence of numerous crypts along the primary and secondary ducts was also noted (Fig. 1b).

The PAS staining demonstrated the presence of secretory cells containing PASpositive (purple - neutral mucosubstance) granules near the lumen (primary and secondary ducts). The PAS-positive reaction was observed in the epithelial cells of
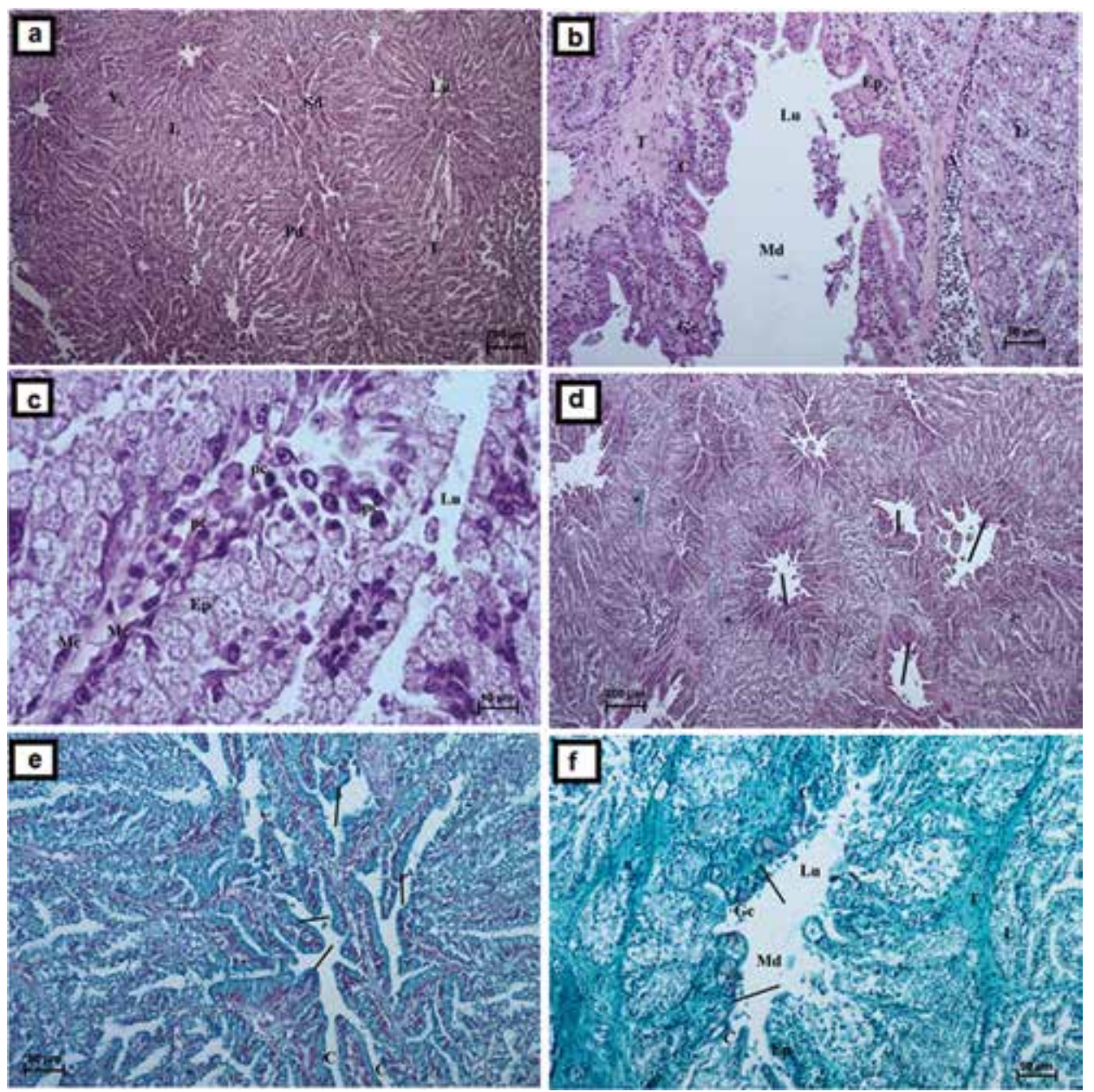

Fig. 1. Light micrograph of the HG of Bilgorajska geese. a. H\&E stain. T - trabeculae, $\mathrm{L}-$ lobus, $\mathrm{Lu}-$ lumen, $\mathrm{Pd}$ - primary duct, Sd - secondary duct, V - vessel. Bar $=200 \mu \mathrm{m}$; b. H\&E stain. T - trabeculae, $\mathrm{L}$ - lobus, $\mathrm{Lu}$ - lumen, $\mathrm{Md}$ - main duct, Gc - goblet cells, $\mathrm{C}$ - crypts, Ep - epithelial cells, V - vessel. $\mathrm{Bar}=50 \mu \mathrm{m} ; \mathbf{c} . \mathrm{H} \& \mathrm{E}$ stain. $\mathrm{Lu}-$ lumen, $\mathrm{Pc}-$ plasma cells, Mc - myoepithelial cells, Ep - epithelial cells, Bar $=10 \mu \mathrm{m}$; d. periodic acid-Schiff stain. Arrow - PAS $(+)$ secretory epithelial cells. Bar $=200 \mu \mathrm{m}$; e. Alcian blue pH 2.5 stain. Arrow - Alcian blue pH $2.5(+)$ secretory epithelial cells, $\mathrm{C}-$ crypts. Bar $=$ $50 \mu \mathrm{m}$; f. AF stain. Arrow - Aldehyde fuchsin (+) secretory epithelial cells. T - trabeculae, $\mathrm{L}-$ lobus,

$\mathrm{Lu}$ - lumen, $\mathrm{Md}-$ main duct, Gc - goblet cells, $\mathrm{C}-$ crypts, $\mathrm{Ep}-$ epithelial cells. $\mathrm{Bar}=50 \mu \mathrm{m}$ 
the main duct (Fig. 1d). The staining with $\mathrm{AB}$ pH 2.5 (blue - acid mucosubstance) method demonstrated the presence of positive granules in the glandular units and main duct (Fig. 1e). AF staining (central cells were intensely blue) detected the presence of carboxylated acid mucopolysaccharides (Fig. 1f). Similarly, HDI staining
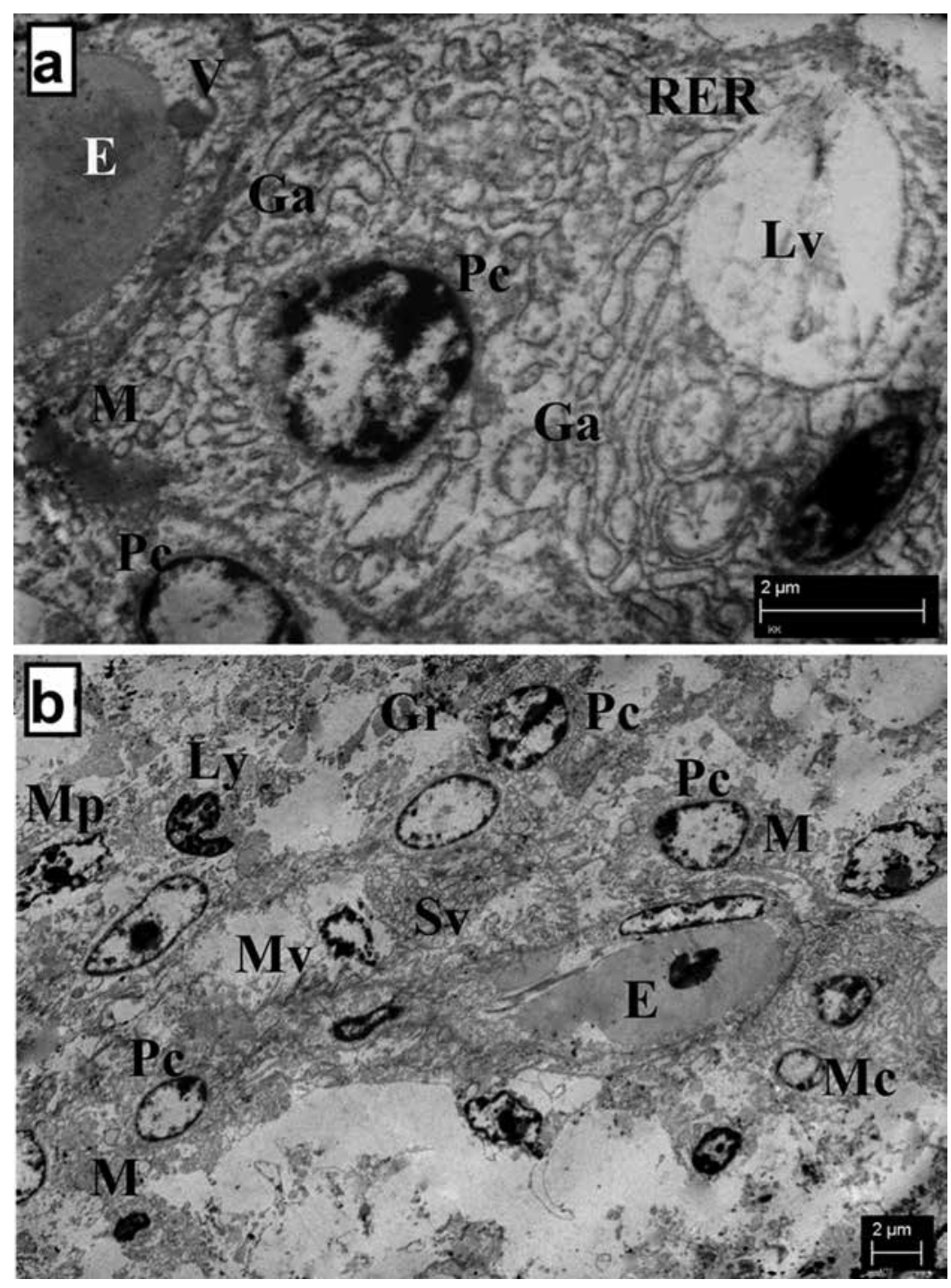

Fig. 2. Electron micrograph of the HG of Bilgorajska geese: a. plasma cells (Pc) in the subepithelial region. RER - rough endoplasmic reticulum, $\mathrm{M}$ - mitochondrion, $\mathrm{Ga}$ - Golgi apparatus, $\mathrm{Lv}$ - lysosomal vesicle, E - erythrocyte, V - vessel. Bar $=2 \mu \mathrm{m}$; b. Pc - plasma cells, Mc - myoepithelial cell, $\mathrm{M}$ - mitochondrion, $\mathrm{Mv}$ - microvilli, $\mathrm{Sv}$ - secretory vesicles, $\mathrm{E}$ - erythrocyte, $\mathrm{Mp}$ - macrophage, Ly lymphocyte, $\mathrm{Gr}-$ high electron-dense granules. Bar $=2 \mu \mathrm{m}$ 
(strong blue colour - highly positive reaction in the primary and secondary ducts, and lighter blue - weakly positive reaction in the peripheral cells) revealed the presence of carboxylated acid mucopolysaccharides.

The HG had a compound tubular structure. The secretory cells composed the connective tissue while interlobular trabeculae formed the stroma of the gland. The gland lumen was lined by columnar epithelial cells with ovoid nuclei located near the base of the cells. The TEM study indicated that these nuclei had even chromatin pattern and a single nucleolus. The free apical border of the cells was covered with short microvilli (Fig. 2b). The cytoplasm contained large and small secretory vesicles of varying number. The plasma cells had a large nucleus with condensed heterochromatin and were rich in rough endoplasmic reticulum (RER) (Fig. 2a). The myoepithelial cells were found at the basal lamina of the columnar secretory epithelium. They had an ovoid shape and light-coloured nuclei. Mitochondria were elongated with a light matrix and possessed infrequent transverse cristae. Mitochondria were associated with elements of rough endoplasmic reticulum (RER). The Golgi complex was well developed in supranuclear regions of the cells. The Golgi apparatus was filled with numerous intracytoplasmic secretory vesicles, which varied in size (Fig. 2a). Electron-dense granules were situated in the peripheral regions of each cell.

\section{DISCUSSION}

The present study demonstrated that the HG of the Bilgorajska goose is located at the ventronasal angle of the orbit near inter-orbital septum, between medial rectus muscle, pyramidal and ventral oblique muscle, which was similar to other avian species $[1,5,15,29]$. Macroscopically, the HG was oval in shape and light pink in colour. According to Burns [5], in ducks and pelicans it had nearly hemispherical shape, and in rockhopper penguin the HG was approximately triangular. Boydak and Aydin [3] has observed that the HGs in domestic geese were elongated.

The HG of the Bilgorajska goose was covered with thin connective tissue capsule, which projected inwards to connective tissue trabeculae dividing the stroma of the gland into lobules. We have also detected adipose tissue in the connective tissue trabeculae, as well as large amount of blood vessels, and collagenous and elastic fibres. In domestic geese [3] and in osprey [15] it was also shown that the HGs of these birds were enveloped by a thin connective tissue capsule. Kozlu et al. [15] have found reticular fibres in the capsule in the HG of osprey, while in quail the connective tissue capsule contained collagenous fibres [16]. The presence of reticular and collagenous fibres in the capsule enveloping the HG has previously been reported in domestic geese [3].

Boydak and Aydin [3], as well as Liman and Gülmez [17], showed in their works carried out on domestic geese that HG had tubulo-acinar structure (type I) and apocrine mode of secretion. In osprey, ostrich, and quail, it was reported that the HG of these birds was also tubulo-acinar with columnar epithelial cells of varying height (type I) $[1,15,16]$. Our research indicates that the HG in Bilgorajska goose possesses a merocrine mode of secretion. Generally avian HG has merocrine mode of 
secretion [5, 29]. However, Altunay and Kozlu [1] observed in ostrich a holocrine type of secretion. According to earlier findings on domestic fowl, holocrine or apocrine secretion can occur in addition to merocrine type of secretion [1]. For gland secretion the myoepithelial cells are needed. Our studies have also shown the presence of myoepithelial cells. The myoepithelial cells were found at the basal lamina of the columnar secretory epithelium. They had an ovoid shape and light-coloured nuclei. In addition to the occurrence of these cells in HGs of birds, e.g., in ostrich [1], domestic geese [3], quail [16], osprey [15], native chicken [20] and chicken [10], they were also found in Altantic bottlenose dolphin [24] and South American armadillo [18]. The myoepithelial cells in the HG of chicken can be transformed into myofibroblasts after application of the antigen on the eyeball [10].

Liman and Gülmez [17] who studied the lacrimal gland and the superficial gland of the third eyelid in domestic geese have observed many secretory ducts, while our study shows that the HG of Bilgorajska geese had only one main duct, as in turkey, duck, hen and domestic geese [3]. The main duct in domestic geese have rich clusters of lymphoid nodules near the epithelium of the crypts [3]. In our experiments we have also observed the presence of numerous goblet cells, which were located in the epithelium of the main duct, in the central part of the corpus glandulae. Similar cells were found in domestic geese, turkey, fowl and duck [3, 20]. However, Mobini [20] did not find them in his study conducted on native chickens.

Histochemical experiments performed on HG of Bilgorajska geese revealed positive reactions of PAS and Alcian blue $\mathrm{pH} 2.5$ in the epithelial cells, indicating neutral and acid mucins as well as glycoprotein secretions. The AF and HDI stainings HG showed the presence of carboxylated acid mucopolysaccharides. Similar results were obtained on domestic geese [3, 17], ducks [11], turkey [20] and fowl [15].

Histologically, the HG in Bilgorajska goose had a tubular structure with a single lobule and empties into a wide lumen (type II). According to Burns [5] and Shirama et al. [29], three types of HG can be identified in birds based on the structure of the lobules and type of epithelial cells lining the acini and tubules. Another characteristic feature of the different types of HG is the variable plasma cells population. For the breeding of birds the immune system is very important for protection from infectious disease. In eye this function belong to plasma cells which produce immunoglobulins. The II type of gland, described in research birds, is characterized by a much smaller population of these cells, which does not increase with age. This type of gland structure has been found in ducks [5], whereas type I (tubulo-acinar) has a large agedependent population of plasma cells and is typical of domestic fowl [5, 27, 29]. In type III ("mixed"), plasma cells are located only in the compound tubulo-acinar lobules and not in compound tubular structures, and number of plasma cells increases with age. This type is typical for rook $[5,29]$. Due to the fact that our material consisted of adult birds of same age, we have shown that HG in Bilgorajska goose had a small number of plasma cells, located below the basement membrane of the secondary and primary ducts, near the crypts of the main duct. Between the plasma cells very few lymphocytes were located. By transmission electron microscopy we have demonstrated that the plasma cells had a large nucleus with condensed hetero- 
chromatin and were rich in rough endoplasmatic reticulum. It strongly indicates that the B cells of the bursa Fabrici immigrate into the HG interstitial cells via the blood circulation. These B cells further differentiate into plasma cells and move to the apical parts of the lobules with Ig contents, from where they are released into the duct system [14]. The major classes of immunoglobulins produced by chicken HGs probably belong to the secretory feature of this gland [2].

\section{CONCLUSIONS}

From the three types of structures reported in birds we have demonstrated that the HG in Bilgorajska goose is of type II in terms of histological structure. The physiochemical properties of mucins are of particular importance for aquatic (especially for submerging species) and terrestrial birds, because they are part of the so-called tear film, which among other things is designed to protect the cornea, lubricate the movement of third eyelid and nourish the cornea. Precise knowledge of the gland structure and above all the analysis of immune cells may have a large impact on clinical practice and properly conducted immunization of birds, so important to preserve the health of birds. Due to the increasing human virus infections of respiratory diseases, the research conducted on birds are also of great importance in respect of the protection of human health.

\section{ACKNOWLEDGEMENTS}

This research was supported by statutory research and development activity funds assigned to Faculty of Veterinary Medicine, Wroclaw University of Environmental and Life Sciences. Special thanks to Professor Ewa Łukaszewicz and Artur Kowalczyk from Institute of Animal Breeding, Division of Poultry Breeding, Wroclaw University of Environmental and Life Sciences for providing the research material.

\section{REFERENCES}

1. Altunay, H., Kozlu, T. (2004) The fine structure of the Harderian gland in the ostrich (Struthio camelus). Anat. Histol. Embryol. 33, 141-145.

2. Baba, T., Kawata, T., Matsumoto, K., Kajiwara, T. (1990) Role of the Harderian gland in immunoglobulin A production in chicken lacrimal fluid. Res. Vet. Sci. 49, 20-24.

3. Boydak, M., Aydin, M. F. (2009) Histology of the Harderian gland of domestic geese (Anser anser domesticus). Acta Vet. Brno 78, 199-204.

4. Brobby, G. W. (1972) On the Harderian gland of the domestic duck (Anas platyrhynchos). Morphological and histochemical investigations. Z. Zellforsch. Mikrosk. Anat. 133, 223-230.

5. Burns, R. B. (1992) The Harderian Glands in Birds: Histology and Immunology. Springer-Verlag, Berlin, Heidelberg, pp. 155-163.

6. Buzzell, G. R., Menendes-Pelaez, A. (1992) The interrelationship between the Harderian gland and the neuroendocrine-thyroid axis in rodents. In: Webb, S. M., Hoffman, R. A., Puig-Domingo, M. L., Reiter, R. J. (eds) Harderian Glands. Springer-Verlag, Berlin, Heidelberg, pp. 255-270.

7. Cooch, F. G. (1964) A preliminary study of the survival value of a functional salt gland in prairie anatidae. The Auk 81, 380-393.

8. Chieffi, G., Minucci, S., Di Matteo, L. (1993) The orbital glands of the terrapin Pseudemys scripta in response to osmotic stress: A light and electron microscope study. J. Anat. 183, 21-33. 
9. Chieffi, G., Baccari, G. C., Di Matteo, L., d’İstria, M., Minucci, S., Varriale, B. (1996) Cell biology of the Harderian gland. Int. Rev. Cytol. 168, 1-80.

10. Del Cacho, E. D., Gallego, M., Felices, C., Bascuas, J. A. (1991) Myofibroblasts and myoepithelial cells in the chicken Harderian glands. Histol. Histopathol. 6, 303-308.

11. Dimitrov, D. S., Nikiforov, I. P. (2005) Histological and histochemical studies of Harderian gland, lacrimal gland and bursa of fabricius in mallard ducks (Anas sterilis) with chlamydial infection. Bulg. J. Vet. Med. 8, 119-127.

12. Dimitrov, D. S., Genchev, A. G. (2011) Comparative morphometric investigations of intraorbital glands in Japanese quails (Coturnix coturnix japonica). Bulg. J. Vet. Med. 14, 124-127.

13. Dimitrov, D. (2011) Histometrical investigation on the turkey broiler's third eyelid (Harderian) gland. Agricultural Sci. Tech. 3, 246-248.

14. Khan, M. Z. I., Jahan, M. R., Islam, M. N., Haque, Z., Islam, M. R., Kon, Y. (2007) Immunoglobulin (Ig)-containing plasma cells in the Harderian gland in broiler and native chickens of Bangladesh. Tiss. Cell 39, 141-149.

15. Kozlu, T., Bozkurt, Y. A., Altunay, H., Sari, E. K. (2010) Histological and histochemical studies on the Harderian gland of the osprey (Pandion haliaetus). J. Anim. Vet. Adv. 9, 1875-1879.

16. Kozlu, T., Altunay, H. (2011) Light and electron microscopic studies of the quail (Coturnix coturnix) Harderian gland. J. Anim. Vet. Adv. 10, 932-938.

17. Liman, N., Gülmez, N. (1996) The light microscopic examination on the development of the Harderian gland of the geese (Anser anser). Vet. J. Ankara University 43, 25-30.

18. Marcos, H. J. A., Affanni, J. M. (2005) Anatomy, histology, histochemistry and fine structure of the Harderian gland in the South American armadillo (Chaetophractus villosus, Xenarthra, Mammalia). Anat. Histol. Embryol. 209, 409-424.

19. Menendez, A., Büzzell, G. R. (1992) Harderian gland indoles. In: Webb, S. M., Hoffman, R. A., PuigDomingo, R. J., Reiter, R. J. (eds) Harderian Glands. Springer-Verlag, Berlin, Heidelberg, pp. 219 234

20. Mobini, B. (2012) Histological and histochemical studies on the Harderian gland in native chickens Vet. Med. 57, 404-409.

21. Nomina Anatomica Avium (1993) Second edition. Published by the Club, Cambridge Massachusetts

22. Nomina Anatomica Veterinaria (2012) Fifth edition (revised version). Published by the Editoral Committee, Hannover (Germany), Columbia, MO (U.S.A.), Ghent (Belgium), Sapporo (Japan).

23. Ohshima, K., Hiramatsu, K. (2002) Immunohistochemical localization of three different immunoglobulin classes in the Harderian gland of young chickens. Tiss. Cell 34, 129-133.

24. Ortiz, G. G., Feria-Valasco, A., Tarply, R. L., Bitzer-Quintero, O. K., Rosales-Corral, S. A., VelaquezBrizuela, I. E., Lopez-Navarro, O. G., Reiter, R. J. (2007) The orbital Harderian gland of the male Altantic bottlenose dolpin (Tursiops truncates): A morphological study. Anat. Hist. Embryol. 36, 209-214.

25. Payne, A. P. (1994) The Harderian gland: A tercentennial review. J. Anat. 185, 1-49.

26. Sakai, T. (1992) Comparative anatomy of the mammalian Harderian glands. In: Webb, S. M., Hoffman, R. A., Puig-Domingo, M. L., Reiter, R. J. (eds) Harderian Glands. Springer-Verlag, Berlin, Heidelberg, pp. 7-23.

27. Scott, T. R., Savage, M. L., Olah, I. (1993) Plasma cells of the chickens Harderian gland. Poultry Sci. $72,1273-1279$

28. Shirama, K., Hokano, M. (1992) Harderian glands and their development in laboratory rats and mice In: Webb, S. M., Hoffman, R. A., Puig-Domingo, M. L., Reiter, R. J. (eds) Harderian Glands. Springer-Verlag, Berlin, Heidelberg, pp. 25-51.

29. Shirama, K., Satoh, T., Kitamura, T., Yamada, J. (1996) The avian Harderian gland: Morphology and immunology. Microsc. Res. Tech. 34, 16-27.

30. Spicer, S. C., Henson, J. G. (1967) Methods for localizing mucosubstances in epithelial and connective tissue. In: Bajusz, E., Jamin, F. (eds) Series on Methods and Achievements in Experimental Pathology. Vol. 2. S. Karger Press, Basel, pp. 78-122. 